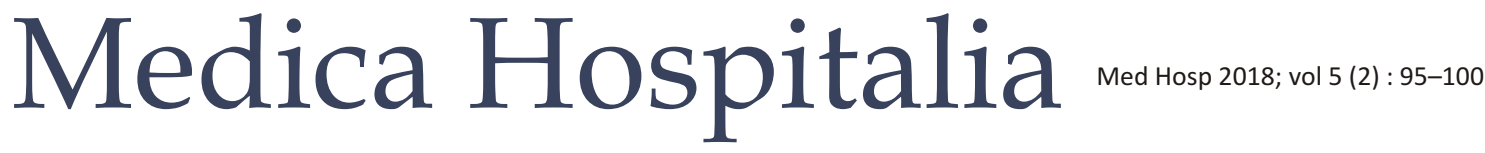

Original Article

\section{Faktor yang Berpengaruh pada Perkembangan Bicara Anak Kurang Dengar yang Menggunakan Alat Bantu Dengar}

\author{
Nastiti Dwi, Muyassaroh \\ Departemen IImu Kesehatan THT-KL FK Universitas Diponegoro/ \\ KSM KTHT-KL RSUP Dr. Kariadi Semarang
}

\begin{abstract}
Abstrak
Latar belakang : Deteksi dini tuli kongenital sudah dilakukan di RSUP Dr. Kariadi. Rata-rata kunjungan anak kurang dengar sejak lahir sebanyak 10-20 pasien per bulan. Salah satu metode intervensi dengan pemakaian alat bantu dengar (ABD). Keluaran penting bagi anak pengguna $A B D$ adalah persepsi bicara, bahasa, kemampuan komunikasi. Tujuan penelitian ini adalah menganalisis faktor yang mempengaruhi perkembangan auditori, bahasa dan wicara pada anak kurang dengar yang menggunakan ABD.

Metode : Penelitian belah lintang. Sampel adalah anak kurang dengar dengan $A B D$ usia pendengaran kurang dari 2 tahun. Data umur pertama memakai alat bantu dengar (ABD), lama penggunaan $A B D$ perhari, jumlah $A B D$ didapatkan dari wawancara. Derajat kurang pendengaran dari hasil BERA. Data kelainan lain pada sampel didapat dari rekam medis. Perkembangan auditori, bahasa dan wicara dinilai dengan LittIEARS Auditory Questionnaire (LEAQ). Analisis data dengan uji Chi Square menggunakan regresi logistic multivariate.

Hasil : Sampel berjumlah 35 anak, 17 (48,6\%) anak menggunakan $A B D$ di usia kurang dari atau sama dengan 3 tahun dan 18 anak $(51,4 \%)$ menggunakan ABD setelah 3 tahun. Data derajat kurang pendengaran profound $80 \%$, sedang-berat $20 \%$. Lama pemakaian ABD diatas 8 jam sebanyak $45,7 \%$ dan $54,3 \%$ anak di bawah 8 jam. Terdapat kelainan lain $20 \%$ dan tanpa kelainan $80 \%$. Frekuensi terapi wicara kurang dari 2 kali perminggu $54,3 \%$ dan lebih dari sama dengan 2 kali perminggu 45,7\%. Hasil LittIEARS Auditory Questionnaire (LEAQ) di bawah kurva 52,4\% dan 47,6\% sesuai kurva normal. Didapatkan agka yang signifikan $(p<0,005)$ pada lama pengunaan alat dan frekuensi terapi wicara.

Simpulan : Lama penggunaan ABD dan frekuensi terapi wicara merupakan faktor yang berpengaruh dalam perkembangan bicara pada anak kurang pendengaran yang menggunakan ABD.
\end{abstract}

Kata kunci : Alat bantu dengar, perkembangan auditori, kurang pendengaran

\section{Factor which influenced auditory, languange and speech development in children using hearing aids}

\begin{abstract}
Background : Early detection of congenital hearing loss has been doing in Kariadi hospital with average 10-20 patients per month. One of intervention methode is hearing aids (HA). The important outcomes are the speech perception, language, and communication skills. This study aimed to analyzed the factor influence auditory, language and speech development in children using hearing aids.

Methods : Cross sectional study. Sample were children with hearing loss who used a hearing aids less than 2 years of age. The first Age fitting $\mathrm{HA}$, duration use of $\mathrm{HA}$, bilateral or unilateral $\mathrm{HA}$ was obtained from the interview. Degree of hearing loss from the BERA results. Other comorbidities were obtained from the medical record. Developments of auditory skill, language and speech was assessed by the LittIEARS Auditory Questionnaire (LEAQ). Data analyze with Chi square test using multivariat logistic regresion.

Results : Sample was 35 children, 17 (48.6\%) children who had used HA less than or equal to 3 years old or 18 children (51.4\%) newly using $\mathrm{HA}$ after 3 years old. $80 \%$ children had profound hearing loss, $20 \%$ moderate-severe hearing loss. Duration of hearing aid usage over 8 hours were $66.7 \%$ and $33.3 \%$ under 8 hours. With other abnormalities $20 \%$ and without other abnormalities $80 \%$. Frequency speech therapy less than twice per week $54.3 \%$ dan more than or equal twice per week $45.5 \%$. The results of LittIEARS Auditory Questionnaire (LEAQ) $52.4 \%$ under curve and $47.6 \%$ normal curve. Significant statistics $(p<0.005)$ were obtained on duration of hearing aid used and frequency speech therapy.

Conclusion : The long-term use of HA and frequency speech therapy are significant factors in the development speech in hearing-impaired children using hearing aid.
\end{abstract}




\section{PENDAHULUAN}

Pendengaran merupakan salah satu indra yang penting bagi manusia, berfungsi sebagai alat komunikasi dan pendidikan. Kurang pendengaran pada anak mengakibatkan keterlambatan dan kesulitan perkembangan bicara dan bahasa serta kognitif. Kurang pendengaran pada anak disebabkan oleh tuli kongenital. ${ }^{1}$ Tuli kongenital dapat disebabkan oleh faktor genetik dan non genetik. Faktor non genetik menjadi penyebab sekitar 25\% dari seluruh tuli kongenital. Faktor genetik diketahui menjadi penyebab lebih dari 50\% tuli congenital. ${ }^{2}$ Menurut WHO, sebanyak 360 juta orang (kira-kira sebesar $5 \%$ dari populasi dunia) hidup dengan gangguan pendengaran dan hampir 32 juta dari mereka adalah anak-anak. ${ }^{3}$ Prevalensi tuli kongenital di seluruh dunia dilaporkan berkisar antara 1-3 kejadian dari 1000 bayi lahir hidup. Survei kesehatan indera pendengaran yang dilakukan Departemen Kesehatan pada 7 provinsi di Indonesia (1994-1996) mendapatkan prevalensi tuli kongenital sebesar $0,1 \%{ }^{1}$ Anak dengan tuli kongenital terdeteksi di klinik Kesehatan THT-KL RSUP Dr. Kariadi menurut data rekam medis rata-rata 10-20 pasien tiap bulan.

Deteksi dini penyimpangan pertumbuhan dan perkembangan anak merupakan tema global utama dalam pelayanan kesehatan anak saat ini. Kegiatan deteksi dimaksudkan untuk menyingkirkan penyimpangan tumbuh kembang anak dan menilai faktor risiko yang mempengaruhinya, dengan harapan tindakan intervensi dapat dilakukan sedini mungkin, sehingga proses tumbuh kembang selanjutnya dapat berlangsung secara optimal. ${ }^{4}$

Intervensi dini dilakukan dengan pemakaian alat bantu dengar (ABD) dan implant koklea. Intervensi akan membantu memberikan rangsang auditorik kepada anak sehingga berpengaruh terhadap kemampuan bicaranya. ${ }^{1}$ Keluaran penting bagi anak pengguna alat bantu dengar adalah persepsi bicara, bahasa, kemampuan komunikasi pada kondisi yang sebenarnya. ${ }^{3}$

Tujuan penelitian ini adalah menganalisis faktor yang mempengaruhi perkembangan bicara anak kurang dengar yang menggunakan alat bantu dengar. Hasil penelitian menjadi bahan edukasi untuk orang tua yang memiliki anak dengan gangguan pendengaran sejak lahir.

\section{METODE}

Penelitian ini adalah penelitian belah lintang. Sampel dari penelitian ini adalah anak kurang dengar sejak lahir yang menggunakan alat bantu dengar dengan usia pendengaran kurang dari 2 tahun dan telah menjalani pemeriksaan BERA di RSUP Dr. Kariadi tahun 2014-2016. Anak dengan kelainan sindrom Down dan cerebral palsy diekslusikan.
LittlEARS Auditory Questionnaire (LEAQ) adalah salah satu alat evaluasi subjektif untuk menilai kemampuan auditori, bicara dan bahasa pada anak dengan kurang pendengaran permanen yang menggunakan alat bantu dengar atau implant koklea. Kuesioner menggambarkan 3 dimensi respon pendengaran : reseptif, semantic, dan produktif. Kuesioner LittlEARS dirancang untuk dijawab oleh orang tua dan tidak dipengaruhi bagaimana kuesioner tersebut ditanyakan. LittlEARS merupakan kuesioner sederhana menggunakan format ya/tidak dan memiliki komponen yang menggambarkan perkembangan anak. Alat ini dikembangkan untuk anak pada umur dua tahun pertama, namun alat tersebut juga masih dapat digunakan pada anak umur lebih dari dua tahun yang lahir prematur, anak dengan perkembangan yang tidak biasa, maupun anak dengan tahap awal penggunaan alat bantu dengar.

Informasi mengenai awal terdiagnosis, awal pemakaian alat bantu dengar, jumlah alat bantu dengar, lama penggunaan alat bantu dengar didapatkan dari wawancara dengan orang tua. Derajat kurang pendengaran didapatkan dari catatan hasil BERA. Kelainan yang dimiliki sampel dinilai dari rekam medis. Analisis data menggunakan analisis multivariate regresi logistik. Hubungan antara variable bebas dan terikat dihubungkan dengan uji Chi Square.

\section{HASIL}

Sampel didapatkan dari 35 anak yang menggunakan alat bantu dengar. Dari data deskriptif didapatkan 17 anak yang telah menggunakan alat bantu dengar di usia kurang dari atau sama dengan 3 tahun atau sebanyak $48,6 \%$ dan didapatkan 18 anak (51,4\%) yang baru menggunakan alat bantu dengar setelah umur 3 tahun. Jumlah alat bantu dengar yang dipakai rata-rata berjumlah 2 buah alat $(82,9 \%)$. Kurang dengar derajat sangat berat (profound) sebanyak $80 \%$, derajat sedang berat sebanyak $20 \%$. Konsistensi atau lama pemakaian ABD dibedakan menjadi 2 kategori yaitu pemakaian di bawah atau sama dengan 8 jam dan pemakaian di atas 8 jam. Didapatkan sebanyak 54,3\% anak menggunakan alat bantu dengar secara tidak konsisten (pemakaian di bawah 8 jam) dan 45,7\% anak secara konsisten memakai alat bantu dengar (lebih dari 8 jam pemakaian). Anak tanpa kelainan lain ditemukan sebanyak $80 \%$ dan $20 \%$ tanpa kelainan lain. Kelainan yang ditemukan berupa keterlambatan motorik dan bibir sumbing. Frekuensi terapi wicara kurang dari 2 kali perminggu sebanyak $54,3 \%$ dan lebih dari atau sama dengan 2 kali per hari sebanyak 45,7\%. Hasil LittlEARS Auditory Questionnaire (LEAQ) disesuaikan dengan umur pendengaran anak didapatkan sebanyak 52,4\% memiliki kurva di bawah rata-rata dan 47,6\% memiliki kurva sesuai atau diatas rata-rata (Tabel1).

Dilakukan uji bivariate dengan menggunakan tes 


\begin{tabular}{|c|c|c|c|}
\hline Variabel & & $\mathbf{F}$ & $\%$ \\
\hline \multirow[t]{2}{*}{ Usia saat menggunakan $A B D$} & $\leq 3$ tahun & 17 & 48,6 \\
\hline & $>3$ tahun & 18 & 51,4 \\
\hline \multirow[t]{2}{*}{ Jumlah ABD } & 1 & 6 & 17,1 \\
\hline & 2 & 29 & 82,9 \\
\hline \multirow[t]{2}{*}{ Derajat kurang pendengaran } & Sedang - berat & 7 & 20 \\
\hline & Sangat berat & 28 & 80 \\
\hline \multirow[t]{2}{*}{ Lama penggunaan alat } & $<8$ jam & 19 & 54,3 \\
\hline & $\geq 8$ jam & 16 & 45,7 \\
\hline \multirow[t]{2}{*}{ Kelainan } & Tanpa kelainan & 28 & 80,0 \\
\hline & Dengan kelainan & 7 & 20,0 \\
\hline \multirow[t]{2}{*}{ Terapi wicara } & $<2 x /$ mgg & 19 & 54,3 \\
\hline & $\geq 2 x / m g g$ & 16 & 45,7 \\
\hline \multirow[t]{2}{*}{ LEAQ } & Di bawah kurva normal & 22 & 62,9 \\
\hline & Sesuai kurva normal & 13 & 37,1 \\
\hline
\end{tabular}

Chi-Square. Dilakukan analisis terhadap usia saat menggunakan alat, jumlah alat bantu dengar, derajat kurang pendengaran, lama penggunaan alat, kelainan pada anak, frekuensi terapi wicara dengan LEAQ (Tabel 2). Lama pemakaian alat, kelaianan lain, dan frekuensi wicara diteruskan kedalam regresi logistik multivariate (Tabel 3). Didapatkan statistik yang signifikan $(p<0,005)$ pada lama pengunaan alat $(p=0.010)$ dan frekuensi terapi wicara $(p=0,010)$. Variabel lama penggunaan ABD memiliki OR 42,626 dengan IK 95\% 2,421-7500,354. Terapi wicara memiliki OR 42,626 dengan IK 95\% 2,421-750,354. Usia saat menggunakan ABD, jumlah ABD yang digunakan, derajat kurang pendengaran, dan kelainan penyerta lain tidak signifikan pada penelitian ini.

\section{DISKUSI}

Kurang pendengaran pada anak dengan berbagai keparahan dapat berdampak negatif pada perkembangan bicara, bahasa, akademis, emosi dan perkembangan psikososial anak apabila terlambat terdeteksi dan mendapatkan intervensi dini. Intervensi dini dengan alat bantu dengar (ABD) dan implant koklea bertujuan mengakses, merangsang, dan menumbuhkan jaringan saraf auditori menembus ke otak sebagai pondasi dari perkembangan bicara dan bahasa, membaca dan akademis. Hipotesis bahwa implantasi dini memberikan perubahan aktif pada jalur auditori sentral didukung oleh bukti yang diberikan oleh Gordon dkk. Neuroplastisitas paling banyak terjadi selama tiga setengah tahun pertama kehidupan. Pertumbuhan otak bayi yang cepat memerlukan intervensi segera, termasuk di dalamnya amplifikasi dan pemberian program yang mendukung pengembangan keterampilan auditori. Tidak adanya impuls suara yang diterima, otak akan menata ulang dirinya untuk menerima masukan dari indra lain terutama dari indra penglihatan, inilah yang disebut dengan cross-capital reorganisasi yang berdampak pada berkurangnya kapasitas saraf auditori. ${ }^{5}$

Kurang pendengaran sensorineural disebabkan oleh kegagalan dalam transduksi suara di koklea dari getaran mekanis telinga tengah menjadi impuls neural pada saraf kranial kedelapan. Kelainan sensori dapat terjadi dari sejumlah perubahan struktur dan fungsi koklea, tapi yang paling rentan adalah struktur sel rambut luar organ corti, yang bertanggung jawab untuk sensitivitas dan keluaran yang baik dari koklea. Didapatkannya gangguan pada proses di koklea menghasilkan berkurangnya sensitivitas sel reseptor koklea, berkurangnya resolusi frekuensi, dan berkurangnya rentang dinamis. Perubahan kompleks pada fungsi koklea memiliki dampak negatif yang signifikan pada suprathreshold auditori. ${ }^{5}$ Perkembangan koklea manusia pada dasarnya telah matang pada saat kelahiran, sementara perkembangan saraf auditori, 
TABEE 2

Hubungan usia saat menggunakan ABD, Jumlah ABD, derajat kurang pendengaran, lama penggunaan ABD, kelainan lain, frekuensi terapi wicara terhadap LEAQ

Kelompok
LEAQ
$<$ LEAQ

$>$ LEAQ

$\%$

45,5

54,5

13,6

86,4

13,6

86,4

81,8

18,2
12

1

27,3

81,8

18,2
7

6

3

10

4

9

1

12

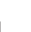

$\%$ $\mathbf{p}^{*}$

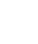




\begin{tabular}{|c|c|c|c|c|c|c|}
\hline \multicolumn{7}{|c|}{ Analisis regresi logistic multivariate } \\
\hline \multirow[t]{2}{*}{ Step } & \multirow[t]{2}{*}{ Variabel } & \multirow[t]{2}{*}{ B } & \multirow[t]{2}{*}{$p$} & \multirow[t]{2}{*}{$\mathbf{O R}$} & \multicolumn{2}{|c|}{ IK 95\% } \\
\hline & & & & & Bawah & Atas \\
\hline \multirow[t]{4}{*}{1} & Lama penggunaan alat & 3,049 & 0,045 & 21,105 & 1,076 & 413,961 \\
\hline & Kelainan & $-2,320$ & 0,197 & 0,098 & 0,003 & 3,324 \\
\hline & Terapi wicara & 4,178 & 0,009 & 65,230 & 2,881 & 1476,670 \\
\hline & Konstanta & $-4,132$ & 0,010 & 0,016 & & \\
\hline \multirow[t]{3}{*}{2} & Lama penggunaan alat & 3,752 & 0,010 & 42,626 & 3,752 & 750,354 \\
\hline & Terapi wicara & 3,752 & 0,010 & 42,626 & 3,752 & 750,354 \\
\hline & Konstanta & $-4,991$ & 0,003 & 0,007 & & \\
\hline
\end{tabular}

percakapan dengan sebaik mungkin. Didapatkan bukti pemberian alat bantu dengar sebelum usia enam bulan dapat memaksimalkan penguasaan bahasa. Alat bantu dengar harus disesuaikan secara optimal, ambang pendengaran harus ditentukan seakurat mungkin, secara terpisah untuk setiap telinga. Alat bantu pendengaran dapat dievaluasi dengan uji wicara (Untuk mereka yang berusia di atas tiga tahun), pengujian preferensi komparatif berpasangan (untuk mereka yang berusia di atas enam tahun), dan pelaporan subyektif oleh anak, orang tua atau guru. Output maksimal yang telah ditentukan harus dievaluasi dengan pengamatan intens pada anak saat suara diberikan dan, bagi mereka yang berusia di atas enam tahun dengan menilai kenyaringan suara. Amplifikasi efektif pada anak tidak mungkin berhasil tanpa dukungan dan pemahaman orangtua. Oleh karena itu klinisi harus menginformasikan dan mendukung orang tua dalam berbagai cara. Bagian dari informasi yang diberikan kepada orang tua mencakup aspek keselamatan amplifikasi dan gangguan pendengaran. Kerugian yang disampaikan termasuk didalamnya pemakaian baterai, paparan kebisingan yang berlebihan, dampak fisik dan kegagalan untuk mendeteksi suara peringatan jika amplifikasi tidak berfungsi dengan benar. ${ }^{9}$

Evaluasi pendengaran pada penelitian ini menggunakan kuesioner LittlEARS. LEAQ digunakan untuk menilai perilaku auditori pada bayi dengan gangguan pendengaran permanen yang memakai alat bantu dengar atau implan koklea. Tiga puluh lima pertanyaan dalam penilaian perkembangan auditori selama dua tahun pertama pendengaran, perilaku auditori semantik serta perilaku ekspresif-vokal. Pertanyaan tergantung tatanan usia dalam format ya / tidak. Total dari semua jawaban 'ya' diakumulasi menjadi skor, dibandingkan dengan nilai rata-rata dan usia minimum. LEAQ dirancang untuk dijawab oleh orang tua dan tidak terpengaruh oleh bagaimana kuesioner itu ditanyakan (yaitu, di bawah bimbingan profesional atau Mandiri). ${ }^{10}$ Pada penelitian ini ditemukan 10 anak yang memiliki perkembangan auditori sesuai dengan kurva umur LEAQ.

Hasil penelitian didapatkan kemampuan auditori bahasa dan wicara dengan usia saat pertama menggunakan ABD secara statistik tidak berpengaruh. Tidak didapatkan perbedaan antara kelompok yang menggunakan ABD sebelum 3 tahun dan setelah 3 tahun. Hal ini sama dengan penelitian yang ditemukan oleh Fitzpatrick dkk. Mereka tidak menemukan hubungan antara usia saat identifikasi atau intervensi dengan hasil keluaran bahasa pada anak-anak dengan gangguan pendengaran. Beberapa penelitian melihat tentang kemampuan bicara, namun tidak menemukan hubungan antara hasil kemampuan bicara dan intervensi awal. ${ }^{6}$ Namun hal ini tidak sesuai dengan studi Yoshinaga-Itano dkk, menyatakan bahwa pengembangan bahasa pada bayi dengan gangguan pendengarannya yang diidentifikasi sebelum usia 6 bulan dan yang menerima intervensi dini segera setelah, memiliki kemampuan bahasa yang secara signifikan lebih unggul daripada anak-anak yang diidentifikasi setelah usia 6 bulan. ${ }^{6}$

Konsistensi penggunaan perangkat bisa jadi salah satu dari beberapa faktor yang berkontribusi pada hasil perkembangan auditori pada bayi dengan gangguan pendengaran. Konsistensi penggunaan ABD merupakan tantangan multidisipliner bagi orang tua dengan anak gangguan pendengaran yang menggunakan ABD. Moeller dkk melakukan penelitian tentang konsistensi pemakaian ABD. Moeller dkk menemukan tujuh orang ibu merasa bahwa anak mereka telah mendapatkan manfaat dari pemasangan ABD setelah pemakaian konstan, beberapa ibu melaporkan bahwa mereka melihat perbedaan perilaku yang jelas antara anak 
dengan ABD dan tanpa ABD. ${ }^{11}$

Wake dkk melakukan penelitian terhadap hubungan antara derajat kurang pendengaran dengan perkembangan bahasa. Terdapat hubungan yang jelas antara derajat kurang pendengaran dengan hasil dari perkembangan bahasa, kinerja menurun seiring dengan tingkat kurang pendengaran. Levitt juga menemukan hubungan yang kuat antara derajat kurang pendengaran, dan kejelasan ucapan serta hubungan yang lemah dengan hilangnya pemahaman sintaksis. Pada penelitian ini tidak didapatkan statistik yang signifikan antara LEAQ dengan derajat kurang pendengaran. Hal ini sesuai dengan penelitian Blamey dkk, tidak ditemukan korelasi yang signifikan antara persepsi wicara dengan derajat kurang pendengaran, tidak ditemukan hubungan antara derajat kurang pendengaran dengan perkembangan bicara atau bahasa. ${ }^{6}$

Pada penelitian ini dilakukan analisis mengenai jumlah ABD yang digunakan dan kelainan penyerta lain, namun kedua hal tersebut tidak berpengaruh. Kelainan penyerta lain yang ditemukan pada penelitian ini adalah adanya gangguan perilaku, dan adanya delay pada perkembangan motorik anak, dan terdapatnya bibir sumbing.

Penna dkk menemukan bahwa diskriminasi fonemik, perkembangan leksikal dan fonologis anak kurang dengar derajat sedang-berat adalah kurang baik. Diharapkan dengan penggunan ABD dan terapi wicara, perkembangannya akan mendekati anak normal. Perkembangan bahasa lisan, tulisan dan keterampilan mendengar yang tidak normal mencerminkan konsekuensi dari intervensi terapi wicara. ${ }^{12} \mathrm{Hal}$ ini sesuai dengan hasil penelitian ini didapatkan frekuensi terapi wicara menunjukkan hasil yang signifikan sebagai faktor yang mempengaruhi perkembangan bicara pada anak tuli kongenital. Anak yang menjalani terapi wicara minimal 2 kali perminggu memiliki keluaran bahasa yang lebih baik daripada anak yang hanya menjalani terapi wicara sekali per minggu atau tidak menjalani terapi wicara.

\section{SIMPULAN}

Lama penggunaan alat bantu dengar dan frekuensi terapi wicara berpengaruh terhadap perkembangan bicara pada anak kurang dengar.

\section{DAFTAR PUSTAKA}

1. Nugroho Dimas, Zulfikar, Muyassaroh. Kemampuan auditorik anak tuli kongenital derajat sangat berat dengan dan tanpa alat bantu dengar. Medica hospitalia.2012; Vol.1(2): p.80-2.

2. American speech-language-hearing association. Cause of hearing loss in children. Audiology information series. 2015. www.asha.org.

3. World health organization. Childhood hearing loss; strategies for prevention and care. WHO library cataloguing-inpublication data. 2016: p.1-30.

4. Gunawan Gladys, Destiana R, Rusmil Kusnandi. Gambaran perkembangan bicara dan wicara anak usia 0-3 tahun. Sari Pediatri. 2011; Vol.13(1): p.21-25.

5. Madell jane R, Flexer carol. Why Hearing Is Important in Children. In : Madell. Pediatric audiology: diagnosis, technology, and management.Edisi 2. New York: Thieme Medical Publishers. 2014: p.4-7.

6. Sininger Yvonne S, Grimes Alison, Christensen Elizabeth. Auditory Development in Early Amplified Children: Factors Influencing Auditory-Based Communication Outcomes in Children with Hearing Loss. Ear hear. 2010;31(2): p.166-185.

7. Chi david, Sabo diane. Pdiatric audiology and implantable hearing device. In: Bailey head and neck surgery otolaryngology. Ed 5. Philadelphia. Lippincott Williams\&. WJ.lkins, a Wolters Kluwer business. 2014. p:1505-22.

8. Rundjan Lily, Amir Idham, Suwento Ronny, Mangunatmadja Irawan. Skrining Gangguan Pendengaran pada Neonatus Risiko Tinggi. Sari Pediatri. 2005; Vol. 6(4): p.149-154.

9. De sujata, archabold sie, Clarke ray.Investigation and management deaf child. In:Gleeson Michael. Scott brown's otolaryngology. Ed 7. Great Britain: Edward Arnold (Publishers) Ltd; 2008. p.844-57.

10. Spitzer Jaclyn B, Zavala Jorge S. Development of Spanish version of the LittlEARS parental questionnaire for use in the United States and Latin America. Audiology research. 2011; Vol.1(31), p: 23-29.

11. Moeller Mary Pat, Hoover Brenda, Peterson Barbara, Stelmachowicz Pat. Consistency of Hearing Aid Use in Infants with Early-Identified Hearing Loss. Am J Audiol. 2009 ; Vol.18(1): p:14-23.

12. Penna Leticia M, Lemos Stela M A, Alves Claudia R L. Auditory and language skills of children using hearing aids. Braz J Otorhinolaryngol. 2015;Vol.81(2):p.148-157. 